\title{
Utilization of the Country of Origin Effect in Product-harm Crisis Management: an Overview of Literature and a Conceptual Model Proposition
}

\author{
Dmitry V. Zhukov, Miraj Ahmed Bhuiyan, Asad Ullah \\ Wuhan University of technology, Wuhan, China \\ Corresponding author (e-mail):ahmed.miraz@gmail.com
}

\begin{abstract}
Despite the fact that companies try to put high emphasis on the quality of their products and processes, still, there are unexpected threats to the safety of consumers by failed quality which leads unexpected shock to the normal operation of the company. Product risk can even lead to corporate crisis, mainly because of strategic threats. For the duration of the crisis, companies struggle to minimize the harm brought to their reputation and brand equity. This paper presents a new notion of measuring organizational success when dealing with product-harm crises. It introduces the concept of country of origin as a potential tool in managing the crisis as it gives a comprehensive overview of effects on perceptions and attitudes of consumers towards products from abroad. This can suggest that using positive associations of the country when building a strong brand creates consumers' positive attitude and perception towards country of origin aspect of the brand. The paper suggests that even at the crisis time, perception, attitude, and behavior that lead to willingness of purchase are influenced by aspects related to country of origin. Thus, country of origin has been identified as an important factor that influences successful recovery from a productharm crisis.
\end{abstract}

Key words: Country of origin effect, Consumers' attitudes, Product-harm crisis management, Country image

\section{Introduction}

No matter how much emphasis companies put on safety of their products, certain risks regarding environment or workers' well-being is still inherent in business operations and activities that may consequently lead to crisis. We can even see such incidents in the example of worlds' leading companies, including Mercedes, Kraft, Toyota and Apple where incidents consequently brought

ISSN 1849-5664 (online) http://researchleap.com/category/international-journal-of-management-science-and-business-administration ISSN 1849-5419 (print) International Journal of Management Science And Business Administration Vol 1. No 2. January 2015., pp. 54-70 
damage to the reputation of their brand, and in some cases, even had a health threatening effects on consumers. In a recent incident, Toyota recalled 6.4 million vehicles from the global market due to technical problems which directly and indirectly caused accidents to occur. In addition, Kraft and Eta peanut butter were found to be contaminated with salmonella (van Heerde, Helsen, \& Dekimpe, 2007). During the crisis time, due to product recalls, corporation's financial performance may worsen and its reputation may decrease. As a result of product-harm crisis, organizations experience losses in baseline sales, their marketing instruments become less effective and cross effects of those instruments on the performance and sales of competitor brands also decreases, whereas cross sensitivity to competitors' marketing-mix activities increases. (Dawar, N., \& Pillutla, M. M. 2000). Therefore, it is generally assumed that it is in companies' interest to deal with the product-harm crisis as effectively and as quickly as possible. In prior studies various factors and their contributions to the product-harm crisis have been examined. As consumer attitude is one way of measuring the effectiveness of product crisis management, it is a priority for crisis managers to identify factors critical for ensuring positive attitudes of consumers toward the company and its brand in such situations. (van Heerde, Helsen, \& Dekimpe, 2007).

In this paper, we introduce the concept of country of origin as a potential relevant factor in productharm crisis management. The country of origin has received greater emphasis in recent times. The term "Made in" often evokes various reactions and associations to products from consumers illustrating the importance of the country of origin in shaping a reputation of the product or brand. Various features of a country including its history, tradition, culture, economy interact and contribute to the country of origin effect. The impact of country of origin on consumers' attitudes is evident. Country of origin enables consumers to make quick purchasing decision. Country of origin may be utilized especially in times when no other tangible cues are available upon which consumers can rely on forming attitudes and make decisions. Meta-analysis of Liefeld (1993) showed that country image impact consumer evaluation of product quality and risk associated with the product.In the light of the fact that many people prefer brands from some countries over others, it would be interesting and valuable to get insight about their perception and attitude in relation to the country of origin effect in times of product-harm crisis. Given the recognized value of country of origin in forming consumers' attitudes and perception about products and brands in normal times, we could hypothesize its potential impact and value in the time of product-harm crisis.

General objective of this paper is to examine current frameworks concerning country of origin effect on shaping consumer perception and to further analyze the process of product crisis management as a critical organizational function. Lessons learned help construct a conceptual framework upon which effective empirical study can be conducted. To begin with, we explore the concept of product-harm crisis and introduce factors valuable for crisis resolution. Afterwards, we provide a systemized review of country of origin literature in order to clearly depict country of origin effect on consumer attitudes. Through detailed theoretical analysis, a research framework for potential use of country of origin in product-harm crisis management will be proposed. We put effort in connecting two concepts to deliver our main concept, eventually constructing a foundation for future research in product-harm management.

55

ISSN 1849-5664 (online) http://researchleap.com/category/international-journal-of-management-science-and-business-administration ISSN 1849-5419 (print) International Journal of Management Science And Business Administration Vol 1. No 2. January 2015., pp. 54-70 


\section{Product crisis management}

According to Bilkey and Nes (1982), a crisis can be defined in numerous ways, mainly as a considerable threat to operations if not dealt with carefully and promptly, resulting in negative consequences. However, there are three main threats that can occur as a result of a crisis. They are public safety, financial and reputation loss. In this particular case, the definition of a crisis consists of crucial points and conclusions found in various prior studies which refer to what makes up a crisis. A real threat is possible damage to the organization, its stakeholders and whole industry. Crisis like industrial accidents and product-harms can also result in injuries and losses of lives. As it has been mentioned by Dilenschneider (2000), all types of crisis share common features; they bring a financial and market share loss, resulting in lawsuits and finally reflecting on the reputation of a particular organization. More specifically, reputation and financial loss are due to injuries and deaths catastrophes, yet there is also a strong connection between the reputation and financial situation of organizations.

According to Pearson and Mitroff (1993), failure of product crisis management can result in serious harm to stakeholders, losses for an organization, in some cases, it even threats organization's very existence. Therefore, product crisis management is considered as one of the most critical organizational functions in the company. Public safety, reputation and financial concerns are the most primary concerns in product crisis management yet the last two are usually dealt only after public safety has been dealt well. Product crisis management can be divided into three phases; precrisis, crisis response, and post-crisis. The first phase implies prevention and preparation. Crisis response phase occurs as management actually starts responding to a crisis and finally the postcrisis phase means thinking about better ways to prepare for a crisis after commitments made during the crisis (Klein, J., \& Dawar, N. 2004). Therefore, crisis management is designed to protect an organization along with its stakeholders from threats and reduce any impact incurred form threats.

\section{Factors influencing product crisis management}

Coombs, W. T. (1998) states that the type of crisis and that particular situation determine the response that a company or a crisis manager will take, meaning that on a global scale, an open honest proactive approach to crisis communication may be the rightest path to minimize the impacts of the crisis. Prompt product recall after detecting any product-harm can be one good example for proactive approach. However, this approach may have more negative effect on firm value considering the fact that stock market links proactive strategies to substantial financial losses in the organization. Companies managing product recalls must keep in their mind the fact how investors might understand a proactive strategy and be aware of its potential downsides. In this sense, passive strategies tend to be more suitable approach in comparison to proactive strategies. (Chen, Y., Ganesan, S., \& Liu, Y, 2009),

56

ISSN 1849-5664 (online) http://researchleap.com/category/international-journal-of-management-science-and-business-administration ISSN 1849-5419 (print) International Journal of Management Science And Business Administration Vol 1. No 2. January 2015., pp. 54-70 
According to Puchan (2001), the three pervasive factors employed in crisis management that shape the consumer responses and recovery in times of crisis encompass company's reputation and image, external effects from regulatory agencies and the press as well as organizational responses. Time is another important factor that has a major overall impact on the effectiveness of product-harm crisis management. After several months time, consumers' impressions and general idea of the incident fade away. Appropriate handling of the crisis that is voluntary recall of the product and corporate responsibility enhances the influence of the time. As reported by Mowen, J. C., Jolly, D., \& Nickell, G. S. (1981), prior studies have shown evidence that the after-crisis image of companies that had recalled their products was influenced by the notion of the recall, the notion of other companies' recalls, the perceived corporate responsibility and the perceived responsibility for the defect of the companies.

In order to address the crisis, price was one of the many instruments used, in a way that it was decreased in order to attract the consumers or increase because there had been declining sales and compensation of losses was required (Marn, Roegner, \& Zawada, 2003; Cleeren et al, 2013). Along with price, advertising is one of the many approaches and mechanisms used when an incident arises, and organizations want to relocate and separate themselves from the incident.

Advertising is also one of the methods of addressing the crisis that companies use when they want to reposition themselves and distance from the incident. When trying to address a crisis, various symbolic resources are utilized within the messages communicated to consumers. When speculating that one moderately recognized model in terms of measuring product crisis management performance and efficiency in firms is by evaluating and taking into consideration consumers' attitudes, the presumption is there is a potential value in pointing out country of origin when managing product-harm crisis. (Dawar, N., \& Pillutla, M. M. (2000). Seeing as companies often use their country of origin to compose and and building up their image and putting additional value to their product in normal times, it can be also used during a crisis period.

The interaction of expectations and firm response is shown to affect post crisis brand equity. Post crisis brand equity is affected by the interaction of expectations and firm response, taking into account prior expectations of an organization, helping to figure out and better comprehend the manner in which consumers interpret firm response (Pang, A. 2012). According to prior studies by Dawar, N., \& Pillutla, M. M., 2000), positive prediction of an organization or the brand equity is formed partly on the country the company associated with before the crisis. Thus, country of origin is possibly a factor in the crisis time that may be used indirectly as prior equity in order to regain the trust of the consumers or building equity after the crisis. The country of origin has a greater effect for developed countries given the fact that strong brands usually derive from developed countries bearing strong identities. Moreover, when it comes to the purchase of products, brand advertising has much greater influence on stronger than on weaker brands. According to prior research, being familiar and devoted to a certain product, in fact, minimize the effects of a crisis. Further, we introduce the country of origin effect and propose its use in managing product-harm crisis.

57

ISSN 1849-5664 (online) http://researchleap.com/category/international-journal-of-management-science-and-business-administration ISSN 1849-5419 (print) International Journal of Management Science And Business Administration Vol 1. No 2. January 2015., pp. 54-70 


\section{Country of origin effect: An overview and principal theoretical analysis}

\subsection{Country of origin, country of origin effect and country image}

We have witnessed a great economic change in the last 30 years. Faster communication channels, better transportation infrastructure and easier finance flow have all affected the increase in penetration of international products and considerably accelerated international trade. Favorable economic conditions in connection to the increase in size and growth of demand of the consumer market have seen an increase in penetration of international products. This happens also due to increase in people's income and urbanization. Brands such as Swiss watches, German BMWs, and French wines, which have always been linked to their appropriate countries, have now begun to flourish in other countries and thus gain more access. For example, the most desirable brands by Chinese customers are product brands from Apple Inc., Nestle S.A., Chanel S.A., Sony Corp., Samsung Group, Uni-President Enterprises Corp., Panasonic Corp., Nike Inc., Canon Inc. and Starbucks Corporations (Cleeren, K., Dekimpe, M. G., \& Helsen, K. 2008). The fact that fifty-two percent of Chinese consumers whose yearly income surpasses 36.000 US dollars prefer foreign brands more than they do Chinese brands means that in some countries there is a distinctive dominance of foreign products over local brands and products, which implies that there are huge market opportunities for foreign companies to be successful and establish themselves in a promising and rising Chinese market.

There are many relevant concepts related to the COO which are defined in various ways in the existing literature. Those concepts that are essential for setting up a research framework are presented and explained next.

According to Balabanis (2002) and Diamantopoulos (2009), country of origin (COO) is an intangible characteristic of a product which according to the quality and attributes of a certain product, influences the consumers' perception of a product. According to Ozsomer and Cavusgil (1991), country of origin implies the location of the corporate headquarters of the company. It is a place of origin with which a product is associated through branding, promotion, and other means. Papadopoulos and Heslop (1991) specify that country of origin is implanted in brands, favoring or damaging the perceived quality and image of the product. Country of origin effect refers to how customers perceive and evaluate products. According to Roth and Romeo (1992), all depends on which country a certain product is produced in. It is a phenomenon which consumers judge and evaluate products based on country of its origin (Chryssochoidis et al; 2007). Several studies (Bilkey and Nes, 1982; Wang and Lamb 1983) state COO to have a strong influence on product evaluation and purchase decision.

58

ISSN 1849-5664 (online) http://researchleap.com/category/international-journal-of-management-science-and-business-administration ISSN 1849-5419 (print) International Journal of Management Science And Business Administration Vol 1. No 2. January 2015., pp. 54-70 
Meta-analysis by Liefeld (1993) also finds that the country image influences consumer evaluation of product quality, risk, likelihood of purchase and others. An important and crucial part of the country of origin study is the image of a certain country. It is almost as important as the country of origin itself as it combines all the ideas, impressions and beliefs of the people of a particular country or place. According to Kotler et al., country image consists of cognitive, affective and conative dimensions and includes national and cultural symbols, economic and political situations, degree of industrialization, values of that country that product associated with (Essoussi and Merunka; 2007). A positive country image implies a positive evaluation of products while a negative country image implies a negative evaluation of products and often poses an impediment to the sales of the product from the very country.

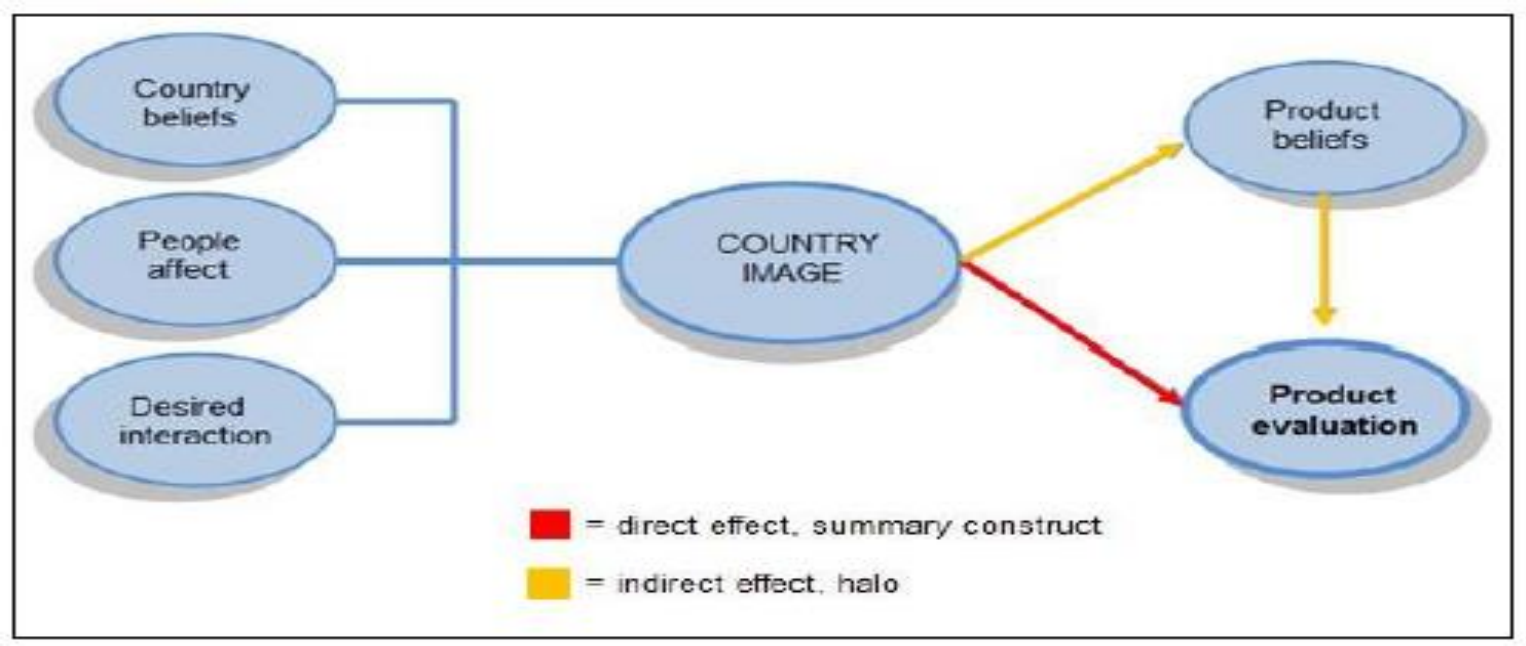

Figure 3-1: Country image model (Laroche et al. 2005)

Taking into account both the halo and summary views, Laroche et al. (2005), constructed a threedimensional country image explaining country image to have an extra indirect effect on product evaluation which affects consumer purchase behavior. According to the model, country image has indirect effect on product evaluation by the customer through product beliefs. The consumers' beliefs about a product's intrinsic characteristics such as reliability, technical advance, performance and workmanship together with country image influence consumers' product evaluations.

\subsection{Impact of Country-of-origin effect on Consumers'}

\section{Attitudes}

Intrinsic and extrinsic informational product indications, according to Ulgado and Lee (1997), are both used as the basis for the evaluation of products. Intrinsic cues involve the physical composition of a product, but extrinsic cues are not part of the physical product. However, extrinsic cues are still

59

ISSN 1849-5664 (online) http://researchleap.com/category/international-journal-of-management-science-and-business-administration ISSN 1849-5419 (print) International Journal of Management Science And Business Administration Vol 1. No 2. January 2015., pp. 54-70 
product related. Physical modification of the product is not necessary in order to manage retailer reputation, brand name of the product and country of origin of the product (Verlegh and Steenkamp, 1999). Furthermore, all of the aforementioned are considered as extrinsic cues and constitute a part of the total image of a product, thus having an impact on the consumers' perception but not influencing directly the product's performance. Examining the impact of products' warranty on consumers' evaluations, Purohit \& Srivastava (2001) proved warranty to be a signal of product quality. Researchers have all agreed on the importance of country image as a signal in consumers' performance or quality perception.

Regarding product characteristics, Steenkamp (1990) with the study of country of origin as a cognitive indication concludes that extrinsic indications such as country of origin may be used as a signal. According to Pinson (1986), the predictive value of such a cue is affected by the theoretical or intuitive relationship between a product characteristic and indication. For example, according to Broniarczyk \& Alba (1994), the perception of the quality of the German car industry and technology can have an effect on one's preference for German cars, Mercedes and BMW, and have an influence on consumer buying behavior, meaning that country of origin often serves an indicator of product quality and performance. Research has shown that country of origin serves as a signal for product quality and performance. According to Erickson et al. (1984), the country image often has an influence on the overall product evaluation, i.e., the "halo effect".

\section{Country of origin impact in existing research framework and its potential utilization in the product- harm crisis}

\subsection{Country of origin on consumers' product and brand evaluation}

The effectiveness of product-harm crisis management can be heavily influenced by the country of origin as it is one of the most important factors of shaping attitudes of consumers. Consequently, we derive that country of origin is an important product-harm crisis management tool. For that reason, we explore the value of country of origin in affecting consumers' attitudes and perception. Prior studies have shown that country of origin is not just a cognitive indication but rather a multidimensional fabrication. The effect of country of origin, according to Hong and Wyer (1989), can have a direct impact on consumer decision making, has an emotional and symbolic meaning to consumers, playing a crucial role in shaping the consumers' opinion towards products. Consumers are also affected by direct and indirect experience in foreign countries, meeting with foreigners, education abroad or cultural exposure for some time.

60

ISSN 1849-5664 (online) http://researchleap.com/category/international-journal-of-management-science-and-business-administration ISSN 1849-5419 (print) International Journal of Management Science And Business Administration Vol 1. No 2. January 2015., pp. 54-70 
Case in point, Israeli instruments may be considered negatively by Arab-Americans, despite the fact that they show superior quality. This negative attitude towards Israeli products was identified by Obermiller and Spangenberg (1989) research. As an addition, according to Fournier (1998), a second generation Italian-American woman may be strongly connected to Italian products due to their country of origin, along with the quality of the product. When making purchases some consumers may relate country of origin to personal memories, national identities and feelings of national "pride". At the same time, country of origin may also be associated with status, authenticity and exoticness (Verlegh \& Steenkamp; 1999). As an example, according to prior research by Jaffe and Carlos (1995) the factor known as "proud to own" can have a considerable impact on product purchases from the United States and Japan. Country of origin may have an impact on consumer product evaluations and buying decisions even after performance and quality control, an effect which can be elaborated and plays a crucial role in shaping consumer purchase behaviors. In times of crisis, these beliefs can be strengthened or weakened depending on the situation. Thus, since country of origin have a positive contribution towards consumers' evaluation, in times of crisis, country of origin tool may be used to ensure the consumer of general quality and safety of products from that particular country and help him forget "the incident" as quick as possible. Since an attitude towards a certain country is built over a long time of interaction; it is not easy, due to one single incident that attitude would change overnight. Even though sales of the product may be affected for short time period, the belief of an organization in the overall quality or positive associations related to country of origin would prevail after the initial setback.

\section{Proposition 1 - Country of origin plays a role in managing product-harm crisis}

Proposition 2 - The product service or a tourism destination will be evaluated favorably or unfavorably depending on the country of origin, given that the consumer knows the country of origin

Proposition 3 - The evaluation and consumer behavior will also depend on the country of origin in time of product-harm crisis

A brand or product can be perceived in different ways. Most likely, a consumer derives his/her perception of a brand based on the sum of interactions he had with it. During a crisis period, this interaction brings a negative effect on the brand equity. A deep understanding of customers by the company can deliver a brand promise. According to $\mathrm{Li}$ and Wyer (1994), there are three ways in which the country of origin can have influence on the perception of brand quality: as an independent product attribute, as a signal, and as a heuristic. According to Verlegh and Steenkamp, (1999), country of origin has a bigger influence on the perception of quality than it has on the actual purchase. The reason is because there are more indications involved in the process of buying a product which influences the actual purchase. There is a distinction between two types of product, those are utilitarian and hedonic goods, (Agrawal and Kamakura, 1999) when it comes to understand the influence of the country of origin better. Utilitarian goods, also known as search

61

ISSN 1849-5664 (online) http://researchleap.com/category/international-journal-of-management-science-and-business-administration ISSN 1849-5419 (print) International Journal of Management Science And Business Administration Vol 1. No 2. January 2015., pp. 54-70 
goods, are easily comparable based on rational information. Because, the underlying information of these products is accessible. On the other hand, there are hedonic goods, goods from which the quality cannot be determined at fore hand and the perceived quality cannot be based on facts. Studies have shown utilitarian goods are less dependent on extrinsic indications such as country of origin, while country of origin has a greater influence on the actual purchase decision with hedonistic goods. Research performed by Lans, Ittersum, Cicco and Loseby (2001) has demonstrated that hedonic goods are determined by the country of origin because a preference for products from specific countries is existent.

Proposition 4 - Country of origin is significant in product-harm crisis attitude formation for hedonic goods, and insignificant for utilitarian goods

\subsection{Country of origin effect measures}

Schooler (1965), along with other numerous studies, have proven that products produced in less developed countries are not evaluated as quality products. According to Nagashima (1970) consumers were biased for or against products from a less developed country when they were evaluating products made in such countries. There were numerous findings in studies; the most significant is that there was proven statistical significance of relationship between general country and product attributes. Product attributes together with country attributes affects purchase intention of the customer. The price variety was demonstrated by Niffenegger, et al.'s (1980), whose study demonstrated that British products were seen as more technically advanced than products made in France. On the other hand, US products were seen as technically advanced in nature, produced by mass production methods and with a higher degree of advertising, which enabled them to gain more appeal to younger markets. Johansson et al. (1985) stated that products made in favorable countries were rated higher in joint evaluation mode than in separate evaluation mode, while products made in unfavorable countries were better evaluated in separate evaluation mode than in joint evaluation mode.

According to Roth and Romeo (1992), a study was fabricated to determine which dimensions among innovativeness, design, prestige and workmanship were most frequently linked with the image of a certain country; aforementioned characteristics in various product categories. According to the results, the country of origin of a certain product does, in fact, influence product evaluation. Various intrinsic indications, i.e. characteristics of a product such as design, test and performance, have a bigger impact on quality judgments than extrinsic indications associated with the product such as price, brand name and warranties, which lead only to a small and limited influence on product quality perceptions. (Thakor and Katsanis, 1997).

Proposition 5 - The influence of country of origin effect may be different for various product categories in times of crisis

62

ISSN 1849-5664 (online) http://researchleap.com/category/international-journal-of-management-science-and-business-administration ISSN 1849-5419 (print) International Journal of Management Science And Business Administration Vol 1. No 2. January 2015., pp. 54-70 
Proposition 6 - Different consumer segments may be influenced by the country of origin differently

\subsection{COO degree of economic development}

Today, it is worthwhile investigating if there is a big influence of the effect of country of origin in a highly globalized market environment. There has been a significant positive connection between the degrees of economic development of the country of product origin with product evaluation. (Wall \& Liefeld, 1991). According to Granzin \& Okechuku \& Onyemah, (1999), consumers in less developed countries see domestic products less favorable when compared to products from more advanced countries. According to Schooler and Wildt (1968), countries such as Japan, Korea, China and Mexico, have demonstrate the path on how to achieve success in developing their market share by enhancing the origin images of their products.

Proposition 7 - The economic development of the country is a strong indicator of country of origin effect

Proposition 8 - Products from countries with higher reputation will recover better from product-harm crisis than those of countries with lower reputation

Proposition 9- For countries with favorable reputation and positive country of origin effect, the country of origin effect can be used as a factor in managing product-harm crisis, whereas in others the use of it would be counterproductive

\section{Discussion}

This study focused on explaining the importance of building a country image, reputation, gain an understanding of the miscellaneous concept of country of origin effect in order to make the buying of the country's products in other countries more accessible and to ascertain how country image can affect consumers' product evaluations. The country of origin is focused on explaining all the factors and aspects which determine the quality of a certain product, particularly for products for which exists difficulties in determining the quality, in advance. Along with quality, which can modify the perception of the consumer when comparing products, the emotional meaning of the country of origin is crucial. Furthermore, the symbolic meaning of the country of origin is very important as it allows consumers to have a relationship with a country by growing up in that country or having positive relationship with that country to which they identify themselves with (Niss, 1995). According to Lekhoff-Hagius and Mason (1993), the symbolic and emotional connections that people develop "transform country of origin into an expressive attribute which then enhances the positive view towards the products from that country." Given the evident influence of country of origin on consumers' attitudes we suggest to utilize the country of origin effect in managing

63

ISSN 1849-5664 (online) http://researchleap.com/category/international-journal-of-management-science-and-business-administration ISSN 1849-5419 (print) International Journal of Management Science And Business Administration Vol 1. No 2. January 2015., pp. 54-70 
product-harm crises. Product-harm crises frequently creates financial loss by recalls, disrupting operations, affecting the companies' reputation and brand, or spawning lawsuits related to the crisis.

Decisions need to be brought quickly to limit the damage to an organization, meaning that crisis management is a very demanding task. As country of origin plays an important role in shaping the perception of consumers about the products in time of product-harm crisis, it can be used as a valuable marketing communication during the crises time. However, for countries with favorable reputation and positive country of origin effect, the country of origin effect can be used as a factor in managing product-harm crisis, whereas in others the use of it would be counterproductive. Additionally, products from countries with higher reputation will recover better from product-harm crisis than those of countries with lower reputation. Consequently, we can determine that the economic development of the country is a strong indicator of its reputation and country of origin effect. Benefiting from country of origin effect is also equal across all product and consumer segments. The influence of country of origin effect may be different for various product categories in times of crisis whereas different consumer segments may be influenced by the country of origin differently. This means that country of origin effect utilization in product-harm crisis definitely deserves more research and empirical evidence.

\section{Future studies and conclusion}

In conclusion, in order to make the future research on this topic more relevant and with a higher level of validity, improvements in country of origin and country image studies are essential. There is a lack of an extensive research on country image, country of origin effect, researches on productharm crisis. Based on the theoretical foundation built by our study an empirical analysis is advised. By conducting a study which centers evaluating country of origin of product in the minds of customers in times of product-harm crisis, existing research gaps would be filled. Such study would result in findings related to the understanding consumers and the position of the countries' products, services and the country itself in comparison with other competing countries. The insight on how to utilize the country of origin effect to manage product-harm crisis would be of a great value to both governments and organizations. A number of research objectives can be derived from our study for future studies. Therefore, we list the potential objectives for future studies derived from our research. Research objectives for future studies are to try and determine how the country of origin effect has influence on consumers for specific countries in times of product-harm crisis, provide companies information for effective product-crisis management, identify and systematically present to which extent certain countries and companies have employed the country of origin in managing product-harm crisis, determine to which extent certain countries have a favorable position over other countries in the mind of consumers in time of crisis, identify branding and positioning methods that will enable countries and companies to penetrate consumers mind effectively by utilizing the country of origin effect and finally present a thorough analysis of consumers perception of products and services depending on the country of origin for the countries in question and how they react to it in time of crisis.

64

ISSN 1849-5664 (online) http://researchleap.com/category/international-journal-of-management-science-and-business-administration ISSN 1849-5419 (print) International Journal of Management Science And Business Administration Vol 1. No 2. January 2015., pp. 54-70 


\section{References}

- Aaker, D.A. (1991). Managing Brand Equity. The Free Press, New York, NY

- Agrawal, J. and Kamakura, W. A. (1999) Country of Origin: A competitive advantage? International Journal of Research in Marketing, 16, 255-267.

- Alain d'Astous, Lilia Boujbel, Positioning countries on personality dimensions: Scale development and implications for country marketing, Journal of Business Research 60 (2007) 231-239

- $\quad$ Andehn Mikael, Berg Per Olof, Place-of-Origin Effects A conceptual framework based on a literature review

- Bruno Godey, Daniele Pederzoli and others, Brand and country-of-origin effect on consumers' decision to purchase luxury products, Journal of Business Research 65 (2012) $1461-1470$

- Balabanis G, Mueller R, Melewar TC. The human values' lenses of country of or igin images. Int Mark Rev 2002;19(6):582 -610.

- Balabanis G, Mueller R, Melewar TC. In-group and out-group orientations and their relation to formation of Country-of-Origin image stereotypes. Int J Bus Glob 2007;1(3):328 - 44.

- $\quad$ Batra, R., Ramaswamy, V., Alden, D.L., Steenkamp, J.B. and Ramachander, S. (2000) Effects of Brand Local and Nonlocal Origin on Consumer Attitudes in Developing Countries. Journal of Consumer Psychology, 9, 2, 83-95.

- $\quad$ Bilkey, W. J., \& Nes, E. (1982). Country-of-origin effects on product evaluations. Journal of international business studies, 89-99.

- Brijs K. Unravel ling Country-of-Origin- semiotics as a theoretical basis for a meaningcentred approach towards Country-of-Origin effects. PhD Dissertation, Nijmegen, the Netherlands: Radboud Univrsiteit Nijmegen, 2006.

- Broniarczyk, S. M., \& Alba, J. W. (1994). The role of consumers' intentions in inference making. Journal of Consumer Research, 21, 393-407.

- C. Min Han, Testing the role of country image in consumer choice behavior European Journal on Marketing 24,6

- Chao, P. (1993). Partitioning country-of-origin effects: Consumer evaluations of a hybrid product. Journal of International Business Studies, 24, 291-306.

- Chao, P. (1998). Impact of country-of-origin dimensions on product quality and design quality perceptions. Journal of Business Research

- Chen, Y., Ganesan, S., \& Liu, Y. (2009). Does a firm's product-recall strategy affect its financial value? An examination of strategic alternatives during product-harm crises. Journal of Marketing, 73(6), 214-226.

- Chengting Lai, Xiang (Robert) Li, Rich Harrell, Chinese outbound tourists' perceived constraints to visiting the United States, Tourism Management 37 (2013) 136e146

- Chryssochoidis, G., Krystallis, A., \& Perreas, P. (2007). Ethnocentric beliefs and country-oforigin (COO) effect: Impact of country, product and product attributes on Greek consumers' evaluation of food products. European Journal of Marketing, 41(11/12), 1518-1544.

65

ISSN 1849-5664 (online) http://researchleap.com/category/international-journal-of-management-science-and-business-administration ISSN 1849-5419 (print) International Journal of Management Science And Business Administration Vol 1. No 2. January 2015., pp. 54-70 
- Chui Yim Wong, Michael J. Polonsky, Romana Garma, The impact of consumer ethnocentrism and country of origin sub-components for high involvement products on young Chinese consumers' product assessments, Asia Pacific Journal of Marketing and Logistics, Vol. 20 No. 4, 2008, pp. 455-478

- $\quad$ Cleeren, K., van Heerde, H. J., \& Dekimpe, M. G. (2013). Rising from the ashes: How brands and categories can overcome product-harm crises. Journal of Marketing, 77(2), 58-77

- Cleeren, K., Dekimpe, M. G., \& Helsen, K. (2008). Weathering product-harm crises. Journal of the Academy of Marketing Science, 36(2), 262-270.

- Coombs, W. T. (1998). An analytic framework for crisis situations: Better responses from a better understanding of the situation. Journal of public relations research, 10(3), 177-191.

- Dawar, N., \& Pillutla, M. M. (2000). Impact of product-harm crises on brand equity: The moderating role of consumer expectations. Journal of Marketing Research, 37(2), 215-226.

- Deitz, D. M., Standage, B. A., Pinson, C. W., McConnell, D. B., \& Krippaehne, W. W. (1986). Improving the outcome in gallstone ileus. The American journal of surgery, 151(5), 572-576.

- Dilenschneider, R. L. (2000). The corporate communications bible. Beverly Hills.

- Country of Origin Effects on Consumer Willingness to Buy a Product (Application on Pakistan), Electronic copy available at: $\underline{\text { http://ssrn.com/abstract=1545752 }}$

- Dr. Moonkyu Lee, Dr. Yun-Chien Lou, Consumer reliance on intrinsic and extrinsic cues in product evaluations: A conjoint Approach, Journal of Applied Business Research, Volume 12, Number 1

- Durdana Ozretic-Dosen, Vatroslav Skare, Zoran Krupka Assessments of country of origin and brand cues in evaluating a Croatian, western and eastern European food product, Journal of Business Research 60 (2007) 130-136

- Erdener Kaynak, Ali Kara, Consumer perceptions of foreign products:An analysis of product-country images and ethnocentrism, European Journal of Marketing, 36,7/8

- Erickson, G. M., Johansson, J. K., \& Chao, P. (1984). Image variables in multiattribute product evaluations; Country-of-origin effects. Journal of Consumer Research, 11, 694-699.

- Essoussi, L. H., \& Merunka, D. (2007). Consumers' product evaluations in emerging markets: does country of design, country of manufacture, or brand image matter?. International Marketing Review, 24(4), 409-426.

- Fournier, Susan (1998) Consumers and their Brands: Developing Relationship Theory in Consumer Research. Journal of Consumer Research, 24, 343-373.

- Francesca Dall'Olmo Riley, Wendy Lomax \& Angela Blunden, Dove vs. Dior: Extending the Brand Extension Decision-Making Process from Mass to Luxury, Australasian Marketing Journal 12 (3), 2004

- Gaedeke, R. (1973). Consumers' attitudes toward products 'Made In' developing countries. Journal of Retailing, 49, 13-24.

- Gerald Haubl, A cross-national investigation of the effects of country of origin and brand name on the evaluation of a new car, International Marketing Review, 13,5

- Gerard P. Prendergast and Alex S.L. Tsang, Cherry N.W. Chan, The interactive influence of country of origin of brand and product involvement on purchase intention, Journal of Consumer Marketing, 27/2 (2010) 180-188 
- Granzin, K. L., \& Olsen, J. E. (1998). Americans' choice of domestic over foreign products: A matter of helping behavior?. Journal of Business Research, 43(1), 39-54.

- Han, C. M. (1989). Country image: Halo or summary construct? Journal of Marketing Research, 222-229.

- Han, C. M., \& Terpstra, V. (1988). Country-of-origin effects for uni-national and bi- national products. Journal of International Business Studies, 19(2), 235-255.

- Hirschman, E. C. (1986). Humanistic inquiry in marketing research: philosophy, method, and criteria. Journal of marketing Research, 237-249.

- Hong, S. T., \& Wyer, Jr., R. S. (1989). Effects of country of origin and product attribute information on product evaluation: An information processing perspective. Journal of Consumer Research, 16, 175-187.

- Jaffe, E. D., \& Martinez, C. R. (1995). Mexican consumer attitudes towards domestic and foreign made products. Journal of International Consumer Marketing, 7(3), 7-28.

- Javalgi RG, Cutler BD, Winans WA. At you r service! Does Country of Origin research apply to services? J Serv Mark 2001; 15(7):565- 82.

- Josere Bloemer, Kris Brijs, Hans Kasper, The COO-ELM model A theoretical framework for the cognitive processes underlying country of origin-effects, European Journal of Marketing, Vol. 43 No. 1/2, 2009

- Juyan Zhanga, William L. Benoit, Message strategies of Saudi Arabia's image restoration campaign after 9/11, Public Relations Review 30 (2004) 161-167

- Josiassen A, Harzing A-W. Descending from the ivory tower: re flections on th e relevance and future of country-of-origin research. Eur Manag Rev 2008; 5:264 -70.

- Katharina P. Zeugner-Roth, Adamantios Diamantopoulos, Advancing the country image construct: Reply to Samiee's (2009) commentary, Journal of Business Research 63 (2010) 446-449

- Katharina Roth, Adamantios Diamantopoulos, The Country Image Construct: Literature Review and Future Research Needs, 2006 CIMaR Annual Conference Istanbul, May 26-30, 2006

- Keller, K. (1993) Conceptualizing, Measuring, and Managing Customer-based Brand Equity. Journal of Marketing, 57, 1, 1-22.

- Khalid I. Al-Sulaiti, Michael J. Baker, Country of origin effects: a literature review, Marketing Intelligence \& Planning, 16/3 [1998] 150-199, (C) MCB University Press

- Klein JG, Ettenson R, Morris MD. The animosity model of foreign product purc hase: an empirical test in the People's Republic of China. J Mark 1998;62(1): 89-100.

- Klein, J., \& Dawar, N. (2004). Corporate social responsibility and consumers' attributions and brand evaluations in a product-harm crisis. International Journal of research in Marketing, 21(3), 203-217.

- Kotler P., Haider D. H. and Rein I. (1993) Marketing Places: Attracting Investment, Industry, and Tourism to Cities, States, and Nations. New York: Free Press.

- Laroche, M., Papadopoulos, N., Heslop, L. A. and Mourali, M. (2005) The Influence of Country Image Structure on Consumer Evaluations of Foreign Products. International Marketing Review, 22, 1, 96-115.

67

ISSN 1849-5664 (online) http://researchleap.com/category/international-journal-of-management-science-and-business-administration ISSN 1849-5419 (print) International Journal of Management Science And Business Administration Vol 1. No 2. January 2015., pp. 54-70 
- Leclerc F, Schmitt BH, Dubé L. Foreign branding and its effects on product perceptions and attitudes. J Mark Res 1994;31(2):263-70.

- Lee, M., \& Ulgado, F. M. (1997). Consumer evaluations of fast-food services: a crossnational comparison. Journal of Services Marketing, 11(1), 39-52.

- Li, W. K., \& Wyer Jr, R. S. (1994). The role of country of origin in product evaluations: informational and standard-of-comparison effects. Journal of Consumer Psychology, 3(2), 187-212.

- Lillis, C. and Narayana, C. (1974), "Analysis of made in product images - an exploratory study," Journal of International Business Studies, Vol. 5, spring, pp. 119-27.

- Lianxi Zhou, Zhiyong Yang, Michael K. Hui, Non-local or local brands? A multi-level investigation into confidence in brand origin identification and its strategic implications, Journal of the Academic Marketing Science (2010) 38:202-218

- Liefeld, J. P. (1993). Experiments on country-of-origin effects: Review and meta-analysis of effect size. In N. Papadopoulos \& L. A. Heslop (Eds.), Product-Country Images (pp. 117146). New York: International Business Press.

- Li, W.K., \& Wyer, R.S., 1994, The role of country of origin in product evaluations: Informational and standard-of-comparison effects, Journal of Consumer Psychology, Vol. 3, pp. 187-212

- Morello, G. (1984), "The 'made in' issue: a compar-ative research on the image of domestic and foreign products," European Journal, Vol. 12, January, pp. 4-21.

- Mowen, J. C., Jolly, D., \& Nickell, G. S. (1981). Factors influencing consumer responses to product recalls: a regression analysis approach. Advances in Consumer Research, 8(1), 405407.

- Mulder, M. (1977), The Daily Power Game,Martinus Nijhoff, The Netherlands.

- Nagashima, A. (1970), "A comparison of Japanese and US attitudes toward foreign products,"Journal of Marketing, Vol. 34, pp. 68-74.

- Nagashima, A. (1977), "A comparative 'made in' product image survey among Japanese businessmen," Journal of Marketing, Vol. 41,pp. 95-100.

- Niss, H., 1995, Country of origin marketing over the product life cycle, European Journal of Marketing, Vol. 30, No 3, pp. 6-22

- Ming Ming (Grace) Luo, Country-of-Origin (COO) Effect on Chinese Consumers' Evaluation of New Zealand Milk Powder, A thesis submitted to Auckland University of Technology, 2011

- Obermiller, C., \& Spangenberg, E. (1989). Exploring the effects of country of origin labels: an information processing framework. Advances in consumer research, 16(1), 454-459.

- Okechuku, C., \& Onyemah, V. (1999). Nigerian consumer attitudes toward foreign and domestic products. Journal of International Business Studies, 611-622.

- Ozsomer, A., \& Cavusgil, S. T. (1991). Country-of-origin effects on product evaluations: a sequel to Bilkey and Nes review. Enhancing knowledge development in marketing, 2(1991), 269-277.

- Pang, A. (2012). Towards a crisis pre-emptive image management model. Corporate Communications: An International Journal, 17(3), 358-378. 
- Papadopoulos, N. and Heslop, L. A. (2002) Country equity and country branding: Problems and prospects. Journal of Brand Management, 9, 4-5, 294-314.

- Pearson, C. M., \& Mitroff, I. I. (1993). From crisis prone to crisis prepared: A framework for crisis management. The academy of management executive, 7(1), 48-59.

- Puchan, H. (2001). The Mercedes-Benz A-class crisis. Corporate Communications: An International Journal, 6(1), 42-46.

- Purohit, D., \& Srivastava, J. (2001). Effect of manufacturer reputation, retailer reputation, and product warranty on consumer judgments of product quality: a cue diagnosticity framework. Journal of Consumer Psychology, 10(3), 123-134.

- Roth, M. S., \& Romeo, J. B. (1992). Matching Product Catgeory and Country Image Perceptions: A Framework for Managing Country-Of-Origin Effects [corrected title: Matching Product Category and Country Image Perceptions: A Framework for Managing Country-Of-Origin Effects]. Journal of International Business Studies, 477-497.

- Schooler, R. D., \& Wildt, A. R. (1968). Elasticity of product bias. Journal of Marketing research, 78-81.

- Siomkos, G. J., \& Kurzbard, G. (1994). The hidden crisis in product-harm crisis management. European Journal of Marketing, 28(2), 30-41.

- Siomkos, G., \& Shrivastava, P. (1993). Responding to product liability crises. Long Range Planning, 26(5), 72-79.

- Steenkamp, J. B. E. (1990). Conceptual model of the quality perception process. Journal of Business research, 21(4), 309-333.

- Van Heerde, H., Helsen, K., \& Dekimpe, M. G. (2007). The impact of a product-harm crisis on marketing effectiveness. Marketing Science, 26(2), 230-245.

- Van der Lans, I. A., Van Ittersum, K., De Cicco, A., \& Loseby, M. (2001). The role of the region of origin and EU certificates of origin in consumer evaluation of food products. European Review of Agricultural Economics, 28(4), 451-477.

- Vassilikopoulou, A., Siomkos, G., Chatzipanagiotou, K., \& Pantouvakis, A. (2009). Productharm crisis management: Time heals all wounds?. Journal of Retailing and Consumer Services, 16(3), 174-180.

- Verlegh, P. W., \& Steenkamp, J. B. E. (1999). A review and meta-analysis of country-oforigin research. Journal of economic psychology, 20(5), 521-546.

- Wall, M., Liefeld, J., \& Heslop, L. A. (1991). Impact of country-of-origin cues on consumer judgments in multi-cue situations: a covariance analysis. Journal of the Academy of marketing Science, 19(2), 105-113.

- Wang, C. K., \& Lamb, C. W. (1983). The impact of selected environmental forces upon consumers' willingness to buy foreign products. Journal of the Academy of Marketing Science, 11(1-2), 71-84.

- Wright, A. A., \& Lynch Jr, J. G. (1995). Communication effects of advertising versus direct experience when both search and experience attributes are present. Journal of consumer research, 708-718. 
